\section{Time Course Study of Ancymidol for Micropropagation of Hosta in a Liquid Culture System}

\author{
Sonja L. Maki, ${ }^{1}$ Maria Delgado, ${ }^{2}$ and Jeffrey W. Adelberg ${ }^{3}$ \\ Department of Horticulture, Clemson University, Clemson, SC 29634
}

Additional index words. bioassay, growth retardant, sucrose, tissue culture

\begin{abstract}
The gibberellin biosynthesis inhibitor, ancymidol, was used during micropropagation of Hosta 'Blue Vision'. Shoot growth and bud division was monitored every 2 weeks over an 8-week period in media containing $1 \mu \mathrm{M}$ benzyladenine (BA) and various levels of ancymidol $(0,0.1,0.32,1$ and $3.2 \mu \mathrm{M})$. Ancymidol prolonged bud division from 2 to 6 weeks and increased the total number of buds produced. Shoots grown in medium containing ancymidol had greater fresh weight, shorter-broader leaves and less dry weight than those grown without ancymidol. Reduced dry weight of buds grown in the presence of ancymidol was correlated to the depletion of sugars in the medium. A bioassay using 'Saturn' tall rice revealed that ancymidol was active for the entire 8-week culture period.
\end{abstract}

Hosta is currently among the most valuable ornamental crops in the United States (U.S. Department of Agriculture, National Agricultural Service, 1998) and often propagated commercially through tissue culture (Zimmerman, 1996). Maximum bud formation during the multiplication stage (commonly referred to as Stage II) is an important component of laboratory efficiency and is optimized in tissue culture by altering the concentrations of plant growth regulators in the media. Cytokinins are known to increase cell division, break apical dominance and effect source-sink relations (D'Agostino and Kieber, 1999). Benzyladenine (BA) is effective in inducing crown divisions, both in vitro (Hartmann et al., 1997) and in field production (Garner et al., 1998) of hosta offsets.

Gibberellin inhibitors, including ancymidol and paclobutrazol, were found useful in micropropagation by reducing stem and leaf elongation and producing shoots better acclimatized for field conditions (Ziv, 1995). Ancymidol affects gibberellin synthesis by inhibiting oxidative steps in the biosynthesis of ent-kaurene (a gibberellin precursor), most likely through interactions with the active site of the enzyme (Sugavanam, 1984). Ancymidol also increased both starch and soluble sugar concentrations in leaves of liquid cultured Narcissus (Chen and Ziv, 2001, 2003). Greater starch concentrations at meristematic centers preceded enhanced shoot proliferation. Repeated aseptic handling of long, floppy plantlets wet with sugar-rich liquid media during multiplication(stage II), was made easier when plantlet size was reduced by ancymidol and BA in the ornamental elephant ears, Alocasia and Colocasia (Adelberg and

Received for publication 4 June 2004. Accepted for publication 2 Nov. 2004. This work is publication no. 4883 of the SC Agriculture and Forestry Research Service.

${ }^{1}$ Current address: Department of Biology, Carleton College, Northfield, MN 55057.

${ }^{2}$ Current address: Department of Biochemistry and Genetics, Clemson University, Clemson SC 29634.

${ }^{3}$ Corresponding author; e-mail jadlbrg@clemson. edu.
Toler, 2004). Shorter, thickermicrocuttings with reduced leaf area are more resilient to water loss during acclimatization (Ziv, 1994).

Commercial micropropagation uses semisolid agar, despite findings that liquid medium induces more rapid bud division and larger plants due, in part, to greater sugar uptake from liquid medium (Adelberg, 2005a; Adelberg and Toler, 2004). Hosta plantlets produced in liquid medium have increased dry weight and endogenous soluble solids concentrations linearly related to media sucrose levels over the $1 \%$ to $7 \% \mathrm{w} / \mathrm{v}$ range (Gollagunta et al., 2004). Hosta plants grown in liquid medium have greater dry weight and faster root growth in the outdoor nursery compared to those reared in agar-solidified medium (Adelberg et al., 2000).

At high plant densities (330 explants/L) sucrose depletion from liquid media was found to limit growth of elephant ears (Adelberg and Toler, 2004). Plants on agar at similar density did not grow as large or deplete sugar. Abalance must exist between plant biomass and the mass of sugar supplied from the medium. The objective of this study was to use various concentrations of ancymidol over eight weeks in stage II culture medium to retard leaf-elongation during bud division while monitoring sugar uptake.

\section{Materials and Methods}

Plant material. Hosta 'Blue Vision'explants were provided by Southern Sun Inc., Norris SC. Four explants with about two buds each were placed in 180-mLjars (GerberFoods, Asheville, N.C.) containing $35 \mathrm{~mL}$ of liquid tissue culture media and placed in on a continuous orbital shaker $100 \mathrm{rpm}$ shelf with 25 to $35 \mu \mathrm{mol} \cdot \mathrm{s}^{-1} \cdot \mathrm{m}^{-2}$ PAR provided by cool white fluorescent tubes. The photoperiod was 16 hours and temperature was maintained at $22 \pm 1{ }^{\circ} \mathrm{C}$.

Liquid media. The base medium consisted of a modified Murashige and Skoog media (MS) (Murashige and Skoog, 1962) containing addition of $170 \mathrm{mg} \cdot \mathrm{L}^{-1}$ sodium phosphate, increased $\mathrm{CuSO}_{4} \cdot 5 \mathrm{H}_{2} \mathrm{O}$ concentration to 25 $\mathrm{mg} \cdot \mathrm{L}^{-1}$, and excluding potassium iodide $(\mathrm{KI})$. Organic constituents of the medium included (per liter) $0.5 \mathrm{~mL}$ MS vitamin solution (Sigma M-3900), $92 \mathrm{mg}$ adenine hemisulfate, $30 \mathrm{~g}$ sucrose and $1 \mu \mathrm{M}$ benzyladenine. Ancymidol was added base medium to achieve concentrations of $0,0.1,0.32,1.0$, or $3.2 \mu \mathrm{M}$. Media $\mathrm{pH}$ was adjusted to 5.5 before being dispensed into culture vessels.

Experimental design. A completely randomized design was used with four single-jar replications per treatment per harvest time. The number of buds produced per vessel, tissue fresh weight, tissue dry weight and length to width ratio for the largest leaf were recorded every 2 weeks over an 8 -week period. Residual medium content was measured with a BRIX refractometer. Data were subjected to analysis of variance and linear models were fit to least squares at $P=0.05$ (JMP version 3.2.6, SAS Inst., Cary, N.C.). Bud data was transformed with a square root conversion. For clarity of presentation, only data for $0,0.32 \mu \mathrm{M}$ and 3.2 $\mu \mathrm{M}$ ancymidol concentrations were presented for weeks 2 through 8.

Bioassay for media ancymidol concentration. Seed of 'Saturn' tall rice (provided by Richard Dunand, Louisiana State University Rice Research Station) were surfaced sterilized in $200 \mathrm{~mL}$ of $0.525 \% \mathrm{NaOCl}$ (provided as dilute commercial bleach) with a drop of Tween 20 for 10 min followed by two rinses with sterile, distilled water. Disinfested seeds were pregerminated on moistened filter paper in a 9-cm petri dish for $4 \mathrm{~d}$ at $30^{\circ} \mathrm{C}$ in darkness. Imbibed seeds were placed onto 18-cm-diameter Sorbarod (Ilacon Industries, Ltd., U.K.) paper plugs, nine per vessel(Magenta Corp., Chicago, Ill.), saturated with $18 \mathrm{~mL}$ of media from the culture jars. Seedlings were allowed to grow for $6 \mathrm{~d}$ under cool-white fluorescent light at $30^{\circ} \mathrm{C}$ before measuring the second leaf sheath length. The shortest and longest leaf sheath lengths were omitted and an average of seven leaf sheaths per culture vessel was recorded.

\section{Results and Discussion}

Fewer buds were produced in medium without ancymidol (Fig. 1a). In fact the 15 buds per vessel were present after the first 2 weeks of culture at which time bud division had ceased. Addition of $3.2 \mu \mathrm{M}$ ancymidol to the culture medium stimulated the formation of shoot buds with an optimum of about 50 buds per vessel harvested 6 weeks after initiation. Numbers of buds increased with higher concentrations of ancymidol. By week 8 , there was linear relation between number of buds and ancymidol concentration $\left(R^{2}=0.29, P<0.0137\right)$.

Most of the fresh weight gain occurred in weeks 2 through 6 (Fig. 1b). The presence of ancymidol increased fresh weight by about $25 \%$. Dry weight, however, followed different trends (Fig. 1c). Dry weight increased over the entire 8 weeks of culture only in the absence of ancymidol. In the presence of ancymidol, dry weight gain slowed by week 4 and ceased by week 6 . By the week 8 , there was an inverse relation between ancymidol concentration and dry weight $\left(R^{2}=0.39, P<0.0031\right)$, where the higher ancymidol concentrations had the lower dry weights. 


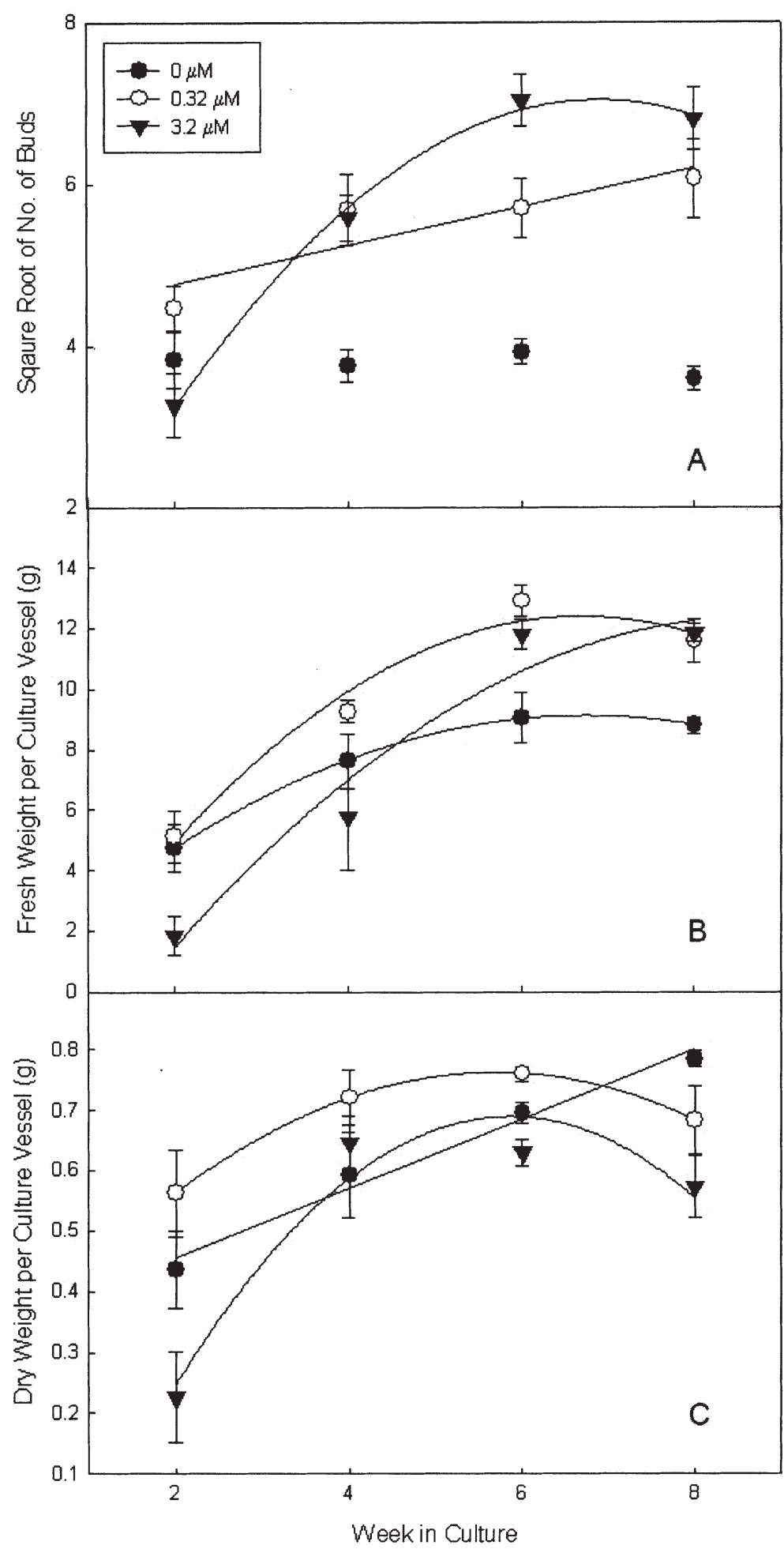

Fig. 1. The effect of ancymidol on (a) the total number of buds produced per culture vessel; (b) explant fresh weight (g) per culture vessel; and c) explant dry weight (g) per culture vessel during an 8-week culture cycle.

Relative dry weight (dry weight/fresh weight) is often used as an index of shoot quality in propagation, and this ratio was affected by ancymidol (Fig. 2a). Relative dry weights were $8 \%$ to $9 \%(95 \% \mathrm{CI})$ throughout the entire 8-week culture cycle in medium without ancymidol. In presence of ancymidol there was a significant reduction in relative dry weight during weeks 2 through 6 , the period of most rapid growth and development. Sugar

residual in media also decreased sharply during this period of most rapid growth (Fig. 2b). In media containing ancymidol, sugar concentration was nil during weeks 6 and 8 , when dry matter accumulation had ceased.

Dry matter accumulation is driven by the difference between sugar levels in the medium and the plant, whereas fresh weight gain is related to the plants' relative water content and the water content of the medium (Ibaraki and Kurata, 1998). When media sugar residuals becomes depleted at high plant densities, tissues grow by taking on more water relative to soluble solids. Residual sugar concentration was directly related to the relative dry weight of plantlets during the 8 -week sampling period $\left(R^{2}\right.$ $=0.69, P<0.0001)$. Sugar concentration was also correlated to relative dry weight in several tissue-cultured species including ornamental elephant ears (Adelberg and Toler, 2004), venus flytrap and watermelon (Adelberg, 2005b).

Hosta 'Blue Vision' has elongated lanceolate leaves. All concentrations of ancymidol ( 0.1 to $3.2 \mu \mathrm{M}$ ) made the leaves smaller, shorter and wider than plantlets without ancymidol (data not shown). A bioassay with the tall rice variety, 'Saturn', revealed no change in ancymidol activity throughout the 8-week cycle (data not shown). The objective of stage II is to multiply shoot buds and leaves are often cut away and discarded during subculture. The use of ancymidol as a growth regulator in the presence of BA shifts growth from the elongated leafblade to the shoot buds. Smaller, denser clumps of shoot bud clusters are easier to manually transfer (Adelberg and Toler, 2004) and also more amenable to mechanical cutting (Alper et al., 1994; Ziv et al., 1994).

Interactions between ancymidol concentrations and media sucrose levels were observed for promotion of asparagus somatic embryos (Li and Wolyn, 1997). Narcissus leaf scales in liquid cultures have higher levels of soluble sugars and starch, prior to the formation of shot bud clusters (Chen and Ziv, 2001, 2003). Ancymidol suppressed leaf elongation and increased the duration of bud multiplication and growth. The concomitant depletion of sugar lowered the dry weight ratio. The use of anycmidol during micropropagation should include observations of sugar adequacy to maintain sufficient dry matter content.

\section{Literatue Cited}

Adelberg J. 2005a. Efficiency in thin-film liquid system for hosta micropropagation. Plant Cell Tissue Organ Cult. (in press).

Adelberg, J. 2005b. Agtiated, thin-films of liquid media for efficient micropropagation. In: S.D. Gupta and Y. Ibaraki (eds.). Plant tissue culture engineering: Frontiers of biology. vol. 6. Springer Scientific Publ., Dordecht, The Netherlands. (in press).

Adelberg J. and J. Toler. 2004. Comparison of agar and thin-film liquid systems for micropropagation of ornamnental Alocasia and Colocasia. HortScience 39:1088-1092.

Adelberg J.M. Kroggel, and J. Toler. 2000. Greenhouse and nursery growth of micropropagated hostas from liquid culture. HortTechnology 10:754-757.

AlperY., R. Young, J. Adelberg, and B. Rhodes. 1994. Mass handling of watermelon microcuttings. Trans. Amer. Soc. Agr. Eng. 37:1337-1343. 


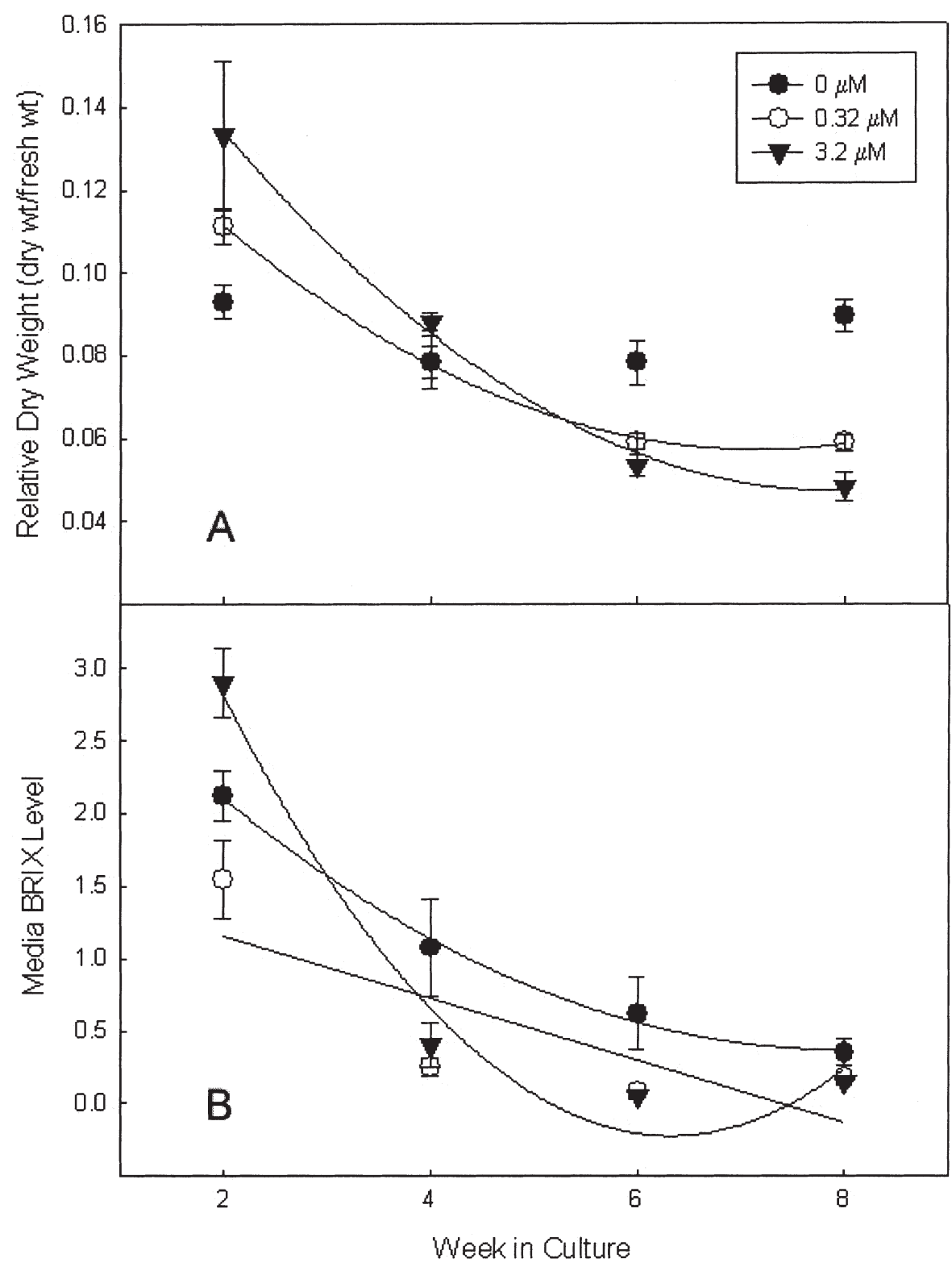

Fig. 2. The effect of ancymidol on (a) relative dry weight and (b) media BRIX levels during an 8-week culture cycle.

on hyperhydricity, regeneration, starch and antioxidant enzymatic activities in liquid-cultured Narcissus. Plant Cell Rpt. 20:22-27.

D’Agostino, I.B. and J.J. Kieber. 1999. Molecular mechanisms of cytokinin action. Current opinions in plant biology, 2:359-364.

Garner J., G. Keever, D. Eakes, and J. Kessler. 1998. Sequential BAapplications enhance offset formation in hosta. HortScience 33:707-709.

Gollagunta V., J.Adelberg, J. Riek, and N. Rajapakse. 2004. Sucrose concentration in liquid media affects soluble carbohydrates, biomass and storage quality of micropropagated hosta. Plant Cell Tissue Org. Cult. 77:125-131.

Hartmann H., D. Kester, F. Davies, and R. Geneve. 1997. Plant propagation: Principles and practices. 6th ed. Prentice-Hall, Upper Saddle River, N.J.

Ibaraki, Y. and K. Kurata. 1998. Relationship between water content of Cymbidium protocorm-like body and growth. In: L.F.M. Marcelis (ed.). Crop models in protected cultivation. Acta. Hort. 456:61-66.

Li, B. and D. Wolyn. 1997. Interactions of ancymidol with sucrose and alpha-napthaleneactetic acid in promoting asparagus (Asparagus officinalis L.) somatic embryogenesis. Plant Cell Rpt. 16:879-883.

Murashige, T. and F. Skoog. 1962. Arevised medium for rapid growth and bio-assays with tobacco tissue cultures. Physiol. Plant. 15:473-497.

Sugavanam, B. 1984. Diastereoisomers and enantiomers of paclobutrazol: their preparation and biological activity. Pest. Sci. 15:296-302.

Zimmerman, R. 1996. Commercial application of tissue culture to horticultural crops in the United States. J. Kor. Soc. Hort. Soc. 37:386-490.

Ziv, M., S. Kahany, and H. Lilien-Kipnis. 1994 Scaled-up proliferation and regeneration of Nerine liquid cultures. Part 1. The induction and maintenance of proliferating meristematic clusters by paclobutrazol in bioreactors. Plant Cell Tiss. Org. Cult. 39:109-115.

Ziv, M. 1995. In vitro acclimitization, p. 493-516. In: J.Aitken-Chrstie, T. Kozai, and M. Lila Smith (eds.). Automation and environmental control in plant tissue organ culture. Kluwer, Dordrecht, The Netherlands. 